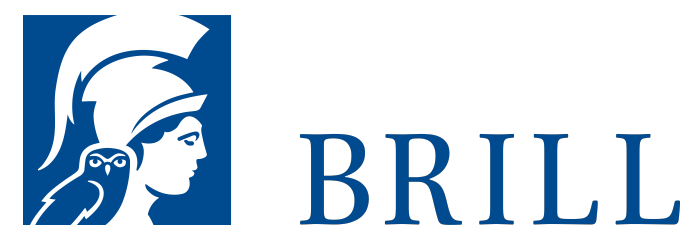

\title{
Women and Curiosity in Early Modern England and France
}

\author{
Authors: Line Cottegnies, John Thompson, and \\ Sandrine Parageau \\ In Women and Curiosity in Early Modern England and France,
} the rehabilitation of female curiosity between the sixteenth and the eighteenth centuries is thoroughly investigated for the first time, in a comparative perspective that confronts two epistemological and religious traditions.

In the context of the early modern blooming "culture of curiosity", women's desire for knowledge made them both curious subjects and curious objects, a double relation to curiosity that is meticulously inquired into by the authors in this volume. The social, literary, theological and philosophical dimensions of women's persistent association with curiosity offer a rich contribution to cultural history.

\section{Readership}

All interested in the history of curiosity in the early modern period, and anyone concerned with gender studies and women's access to knowledge.



Language:

English

Subjects: Early Modern History,

History, Intellectual

History, History, Early Modern Philosophy, Philosophy, Criticism \& Theory,

Literature and Cultural Studies

Publisher: Brill

Series:

Intersections,

Volume: 42

E-Book (PDF)

Released online: o8 Apr 2016

ISBN: 978-90o4-31184-8

List price USD $\$ 171.00$

Hardback

Publication date: 14 Apr 2016

ISBN: 978-9004-31183-1 List price 
Line Cottegnies, Ph.D. (1994), Université Sorbonne Nouvelle Paris 3, is Professor of English Renaissance Literature at that university. She has published widely on Caroline poetry, earlymodern women authors and translation. She also has an interest in editing early modern texts.

Sandrine Parageau, Ph.D. (2008), Université Sorbonne Nouvelle - Paris 3, is lecturer in English history at Université Paris Ouest Nanterre La Défense. She has published Les Ruses de l'ignorance (Paris: 2010), as well as articles and book chapters on women philosophers.

John J. Thompson, D.Phil (1983), Queen's University, Belfast, is Professor of English Textual Cultures in the Institute for Collaborative Research in the Humanities. He is author of two monographs and many essays on English lay reading experience, c. 1300-16oo.

Contributors are Yan Brailowsky, Laetitia Coussement-Boillot, Armel Dubois-Nayt, Adeline Gargam, Sarah Hutton, Neil Kenny, Marie-Gabrielle Lallemand, Laura Levine, Christophe Martin, Marie-Frédérique Pellegrin, Beth Fowkes Tobin, and Susan Wiseman

For more information see brill.com

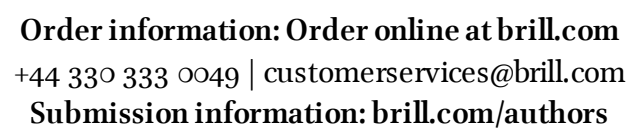

